\title{
Physicians, genetics and life insurance
}

\section{Bartha M. Knoppers, Yann Joly}

Should women who come from at-risk families get life insurance before being tested for genetic susceptibility to breast cancer? Should physicians warn patients who request a genetic test to get life insurance first? How should physicians react to requests from insurance companies for genetic information about their patients?

T

here are no definitive answers to questions such as these. However, a 2003 public opinion survey ${ }^{1}$ revealed that the wide majority of Canadians reject the idea that insurance companies have the right to ask for genetic information even if applicants have personal knowledge of this information. Indeed, the international debate surrounding the role of life insurance, the necessity of risk rating and the notion of "acceptable discrimination" has raised questions about the larger social role of insurance. This debate has been polarized by recent developments in the field of genetics that, in theory, would allow insurers to make use of genetic testing technology as a new underwriting tool.

The importance of genetic information has grown exponentially in the last 20 years. Since the Law Reform Commission of Canada first raised the issue of "insurance testing" in 1991, scientists have completed a draft of the human genome and have identified more than 2 million single nucleotide polymorphisms. ${ }^{2}$ The number of predictive genetic tests offered for monogenic and complex (multifactorial) diseases has multiplied. Nevertheless, only a small portion of the therapeutic possibilities offered by genetics has been realized.

In the United States, the genetics and insurance debate has focused predominantly on access to health insurance. Canada, like most European countries, has a universal health care system, and thus the focus of discussion has been on access to life insurance as a basic socioeconomic good. In Europe, the Convention on Human Rights and Biomedicine (the "Oveido Convention") ratified by 17 countries unambiguously states that genetic testing can be used only for health reasons and for research. ${ }^{3}$ In contrast to the large number of European countries that have clarified their positions regarding the future of genetics and life insurance (see the online table at www.cmaj.ca/cgi/content/full/170/9/1421/DC1), Canada has yet to take a position. Any initiative in this regard should be based on an understanding of how life insurance works, the nature of genetic information, the history of the debate on genetics and life insurance in Canada and the reasons why a Canadian task force decided to take up the challenge.

\section{Life insurance}

Life insurance should be distinguished from social security, disability insurance, unemployment insurance, the Canadian Pension Plan and the principle of universality underlying Canada's health care system. Life insurance is a private contract between the policy-holder and the insurer. Its principal role is to provide income security to the beneficiary in the event of the insured's death.

To calculate the amount of the premium, the insurer uses information such as age, sex, health status and lifestyle as well as some information on the medical history of the insured's family. According to the principle of mutuality underlying insurance, an insured person will then be assigned to a group with similar risk factors. By its very nature, the process of underwriting discriminates between individuals $^{4}$ to pool them into at-risk groups. ${ }^{5,6}$ Unbeknownst to most, $90 \%$ of life insurance applicants are insured at standard rates. ${ }^{7}$

\section{Is genetic information different from medical information?}

Genetic information may alter one's perception of future medical risk. It can affect choices regarding the purchase of life insurance and the premiums to be paid. ${ }^{8} \mathrm{Be}-$ cause of the sensitive, personal, familial and social nature of genetic information, its confidentiality is essential. ${ }^{8}$ At the same time, we must recognize that these characteristics also apply to other types of information about medical risk (e.g., blood pressure, communicable diseases). ${ }^{9}$ However, knowledge of genetic information will permit individuals (and insurance companies) to quantify their own risk with much greater accuracy. For insurance companies, this will mean even greater stratification of risk (risk spreading) and greater variability in premiums charged. Although genetic information may in reality not be different from any other type of actuarial "medical" information, the public perceives genetic information as different. ${ }^{1}$ This fact cannot be discounted or dismissed. 


\section{Insurance and genetics in Canada: historical overview}

The relation between genetics and life insurance became an issue in Canada in 1990 when a Quebec resident's claim for her husband's life insurance was denied by their insurance company. The company argued that the husband had withheld genetic information. The applicant, like other members of his family, had myotonic dystrophy, a genetic disease with variable expression. Having no outward signs of this condition, he answered "No" to the question, "Do you have any anomalies?" The Quebec Superior Court ruled in favour of the insurance company. ${ }^{10}$

Shortly following that incident, the Law Reform Commission of Canada released the study paper "Human dignity and genetic heritage" and suggested that "a basic ... life insurance for all applicants with 'no questions asked' could provide minimum coverage to everyone and avoid problems of discrimination. Additional coverage could be dependent on an agreement by the applicant to be tested for genetic disorders." 11

This was followed in 1996 by the Ontario Law Reform Commission's "Report on genetic testing." 12 This report maintained that:

Insurability is not a trait but a concept of membership. It expresses the criteria used by a group to decide whom to include and exclude from its redistributive system. Treated as a scientific test about individuals, [i]t disguises fundamentally political decisions about membership in a community of mutual responsibility. This issue can be answered only to the extent that the guarantee of a minimum level of insurance in these circumstances can be justified by a collective agreement to accept the diversity, and concomitant expense, of our genetic heritage out of respect for the principles of solidarity and equity.

Finally, in 2001, the Ontario Provincial Advisory Committee on New Predictive Genetic Technologies advised the government to implement a moratorium on the use of genetic information by insurance companies and to create a special commission to make recommendations. ${ }^{13}$

These various reports did not affect the position taken by the insurance industry in Canada. The Canadian Institute of Actuaries, the Canadian Life Insurance Medical Officers Association and the Canadian Life and Health Insurance Association all stated that if genetic testing occurred and the results were available to the insurance applicant, insurers could request access to that information just as it would for other aspects of the applicant's health history. ${ }^{6,14,15}$

In 2003, insurers, patient advocates, geneticists and researchers involved in the Genetics and Society Project of Université de Montréal, funded by Genome Canada (Quebec and Ontario) and in the INHERIT BRCAs Project (Interdisciplinary Health Research International Team on
Breast Cancer Susceptibility) created the Canadian Genetics and Life Insurance Task Force to debate the subject of life insurance and genetics in Canada. The process was both enlightening and difficult. The common aim was to foster debate on a more equitable integration of genetic information in the underwriting process.

Our task force report (see the online appendix at www .cmaj.ca/cgi/content/full/170/9/1421/DC2) suggests debating the following 2 options:

- No use of genetic test results (excluding family history) for a set, moderate amount of insurance coverage for a limited period of time (5 years). This amount and time limit could be revised if warranted.

- Creation of an independent standing body that includes consumers, government, clinicians, industry and researchers for ongoing review of criteria concerning the reliability of genetic information for underwriting purposes. This advisory body could also handle complaints and queries from consumers.

We hope that policy-makers, insurers and physicians will take up the challenge of this task force.

Competing interests: None declared.

The authors are members of the Canadian Genetics and Life Insurance Task Force.

Contributors: Both authors contributed to the writing, conception, intellectual content and design of the manuscript, and critically reviewed and approved the final version.

Acknowledgements: Research funding for the Canadian Genetics and Life Insurance Task Force came from the Canadian Institutes of Health Research, Genome Quebec, the Ontario Genomics Institute and Genome Canada.

\section{References}

1. Government of Canada. Public opinion research into genetic privacy issues. Ottawa: Pollara Research and Earnscliffe Research and Communications; 2003.

2. Lander ES, Linton LM, Birren B, Nusbaum C, Zody MC, Baldwin J, et al; International Human Genome Sequencing Consortium. Initial sequencing and analysis of the human genome. Nature 2001;409:860-921.

3. Council of Europe. Convention for the protection of human rights and dignity of the human being with regard to the application of biology and medicine: convention on buman rights and biomedicine. 1997 Apr 4; Oveido, Spain. Available: http://conventions .coe.int/treaty/en/treaties/html/164.htm (accessed 2004 Mar 22).

4. Daykins CD, Akers DA, MacDonald AS, McGleenan T, Paul D, Turvey PJ. Genetics and insurance: some social policy issues. Br Actuarial 7 2003;9(4): 787-830.

5. Bernheim BD, Carman KC, Gokhale J, Kotlikoff LJ. The mismatch between life insurance holdings and financial vulnerabilities: evidence from the Survey of Consumer Finances. Cambridge (MA): National Bureau of Economic Research, Inc.; 2001. NBER Working Paper 8544.

6. Bernheim BD, Forni L, Gokhale J, Kotlikoff LJ. The mismatch between life insurance holdings and financial vulnerabilities: evidence from the Health and Retirement Study. Am Economic Rev 2003;93(1):354-65.

7. Canadian Institute of Actuaries. Statement on genetic testing and insurance. Ottawa: The Institute; 2000. Available: www.actuaries.ca/publications/2000/20065e.pdf (accessed 2002 Aug 1).

8. Lemmens T. Selective justice, genetic discrimination and insurance: Should we single out genes in our laws? Mc Gill Law 7 2000;45:588.

9. Kosseim P, Letendre M, Knoppers BM. Protecting genetic information: comparison of normative approaches. GenEdit 2003;2. Available: www.humgen .umontreal.ca/en/GenEdit.cfm (accessed 2004 Mar 22).

10. Annick Audet c. L'industrielle-alliance, Cte d'Assurance sur la vie [1990] RRA 500 (Sup Ct).

11. Knoppers BM. Human dignity and genetic heritage. Ottawa: Law Reform Commission of Canada; 1991. p. 50.

12. Ontario Law Reform Commission. Report on genetic testing. Toronto: The Commission; 1996. p. 126. 
13. Provincial Advisory Committee on New Predictive Genetic Technologies. Genetic services in Ontario: mapping the future. Ottawa: The Committee; 2001. p. 27.

14. Canadian Life and Health Insurance Association. CLHIA position statement on genetic testing. Toronto: The Association; 2003.

15. Canadian Life Insurance Medical Officers Association. Guidelines on genetic testing. The Association; 2003.

Correspondence to: Yann Joly, Université de Montréal, CP 6128, succ. Centre Ville, Montréal QC H3C 3J7; fax 514 343-6233; yann.joly@umontreal.ca

\section{Canadian Genetics and Life Insurance Task Force:}

Chair: Bartha M. Knoppers, Genetics and Society Project, Université de Montréal, Montréal, Que., and INHERIT BRCAs Project. Co-chairs: Trudo Lemmens, University of Toronto, Toronto, Ont.; and Béatrice Godard, Genetics and Society Project and INHERIT BRCAs Project. Coordinator: Yann Joly, Genetics and Society Project and INHERIT BRCAs Project. Members: Denise Avard, Genetics and Society Project and INHERIT BRCAs Project; Teren Clark, Muscular Dystrophy Canada, Edmonton, Alta.; Pavel Hamet, Centre hospitalier de I'Université de Montréal, Montréal, Que.; Michael Hoy, University of Guelph, Guelph, Ont.; Sébastien Lanctôt, Heenan Blaikie law firm, Montréal, Que.; Sandy Lowden, LabOne Canada Inc., Markham, Ont.; Huguette Martin, Réseau québécois pour la santé du sein, Montréal, Que.; Christine Maugard, Centre hospitalier de l'Université de Montréal; Yves Millette, Canadian Life and Health Insurance Association Inc., Montréal, Que.; Jacques Simard, Université Laval, Québec, Que., and INHERIT BRCAs Project; Marie-Hélène Vachon, Genetics and Society Project and INHERIT BRCAs Project; Frank Zinatelli, Canadian Life and Health Insurance Association Inc., Toronto, Ont.

\section{CMAJ.JAMCél}

$\mathrm{CMAJ}$ is powered by HighWire Press - the world leader in online journal publishing.

Search all of MEDLINE and access more than 340 highly cited journals, including CMAJ, the New England Journal of Medicine, JAMAA and BMIJ.

\section{Visit www.cmaj.ca to sign up for:}

- email table of contents service

- customized alerts on the topics of particular interest to you

- citation alerts on specific articles

\section{WwW.cmaj.ca}

